\title{
Carbon Dioxide Capture From
} Internal Combustion Engine Exhaust Using Temperature Swing Adsorption

\author{
Shivom Sharma ${ }^{\dagger}$ and François Maréchal ${ }^{*+}$ \\ Industrial Process and Energy Systems Engineering, École Polytechnique Fédérale de Lausanne, EPFL Valais Wallis, Sion, \\ Switzerland
}

OPEN ACCESS

Edited by:

Fateme Rezaei,

Missouri University of Science and Technology, United States

Reviewed by:

Jenny G. Vitillo,

Università dell'Insubria, Italy

Lisa Joss,

University of Manchester,

United Kingdom

*Correspondence:

François Maréchal

francois.marechal@epfl.ch

†These authors have contributed equally to this work

Specialty section:

This article was submitted to Carbon Capture, Storage, and

Utilization,

a section of the journal

Frontiers in Energy Research

Received: 16 May 2019 Accepted: 18 November 2019 Published: 16 December 2019

Citation:

Sharma S and Maréchal F (2019) Carbon Dioxide Capture From Internal Combustion Engine Exhaust Using

Temperature Swing Adsorption.

Front. Energy Res. 7:143.

doi: 10.3389/fenrg.2019.00143
In order to reduce the $\mathrm{CO}_{2}$ emissions in the transportation sector, one can electrify the vehicle, switch to biofuel, or capture and store $\mathrm{CO}_{2}$ on board. In this study, integration of an on board $\mathrm{CO}_{2}$ capture and storage unit with an internal combustion engine has been proposed. The technology can be applied for various internal combustion or Stirling engines with targeted applications in the transportation sector. Truck transport for goods delivery is used as an example for on board $\mathrm{CO}_{2}$ capture and storage system design. The investigated system integrates a temperature swing adsorption system for $\mathrm{CO}_{2}$ capture with a turbo-compressor system to compress and liquefy the captured $\mathrm{CO}_{2}$ using the waste heat of the exhaust gases of the engine. Energy and exergy analyses of the proposed $\mathrm{CO}_{2}$ captured system are studied in details. The $\mathrm{CO}_{2}$ capture system for engine exhaust stream (car, truck, bus, ship, or train) can capture $90 \%$ of the emitted $\mathrm{CO}_{2}$, without any energy penalty. This system can be integrated into overall mobility system (fuel-engine- $\mathrm{CO}_{2}$-fuel), where captured $\mathrm{CO}_{2}$ can be recycled as conventional liquid or gaseous fuels produced from renewable energy sources.

Keywords: carbon dioxide capture, internal combustion engine, exergy analysis, temperature swing adsorption, system design and integration, heat exchanger network

\section{INTRODUCTION}

Among the challenges of the energy transition, reducing $\mathrm{CO}_{2}$ emissions of the transportation sector is one of the most difficult. Electrification of the vehicles is of course a good solution to replace fossil fuel for mobility. This path is however penalized by the density of the electricity storage in the batteries. Fossil fuels are a finite resource, hence they should be replaced by bio-based fuel equivalent. This however requires lots of land that may compete with the food production. $\mathrm{CO}_{2}$ capture is also an alternative, if one can capture with limited energy penalty, and converts captured $\mathrm{CO}_{2}$ into fuels using renewable electricity.

In the year 2014, $\mathrm{CO}_{2}$ emissions due to human activities accounted for about $65 \%$ of greenhouse gas emissions globally (IPCC, 2014). In 2016, transportation sector was accountable for about 28 percent of $\mathrm{CO}_{2}$ emissions in USA (United States Environmental Protection Agency, 2016). In 2016, according to European Automobile Manufacturers Association, 2.7 million commercial vehicles were produced in the European Union. This number shows a huge potential for on board $\mathrm{CO}_{2}$ capture technology for vehicles. However, it could be very difficult to capture $\mathrm{CO}_{2}$ from vehicles due to large number of vehicles. There has been limited research on $\mathrm{CO}_{2}$ capture from vehicles due to mobile nature of source, relatively smaller production rate, discontinuous emissions, space limitation, and on board $\mathrm{CO}_{2}$ storage. Ligterink et al. (2016) has reported $2.65 \mathrm{~kg}$ of $\mathrm{CO}_{2}$ emission per liter diesel consumption by heavy duty vehicles. 
In 2015, according to the European Environment Agency (2017), road transportation sector contributed about 0.746 giga tons $\mathrm{CO}_{2}$ emissions. Hence, $\mathrm{CO}_{2}$ capture from vehicles could be an attractive way to reduce the $\mathrm{CO}_{2}$ emissions significantly.

Figure 1a shows typical composition of exhaust gas from diesel engine. $\mathrm{CO}_{2}$ and pollutant emissions are about 12 and $1 \%\left(\mathrm{CO}, \mathrm{HC}, \mathrm{NO}_{\mathrm{x}}, \mathrm{SO}_{2}, \mathrm{PM}\right)$, respectively (Majewski and Khair, 2006). Figure $\mathbf{1 b}$ presents emission standard of European Union for heavy duty vehicles (Delphi, 2012), NO accounts for $90 \%$ of total $\mathrm{NOx}$ emissions, with the remainder being $\mathrm{NO}_{2}$ (Hebbar, 2014). The diesel engine has an efficiency of about $35 \%$, and about 25 and $40 \%$ energy is lost in cooling system and exhaust heat, respectively (Hossain and Bari, 2014).

For $\mathrm{CO}_{2}$ capture, amine absorption, membrane separation, cryogenic separation and adsorption are main technologies for post combustion $\mathrm{CO}_{2}$ capture from power plant and process industry. The amine absorption for capturing $\mathrm{CO}_{2}$ is commonly used in power plant and process industry including natural gas sweetening (Sharma et al., 2017). The amine absorption process is energy intensive: $3.6-4.0 \mathrm{MJ} / \mathrm{kg}$ using mono-ethanolamine and 2.0-3.8 MJ/kg using advanced amines, for $90 \% \mathrm{CO}_{2}$ capture rate (Bui et al., 2018). For $90 \% \mathrm{CO}_{2}$ capture, performance of amine absorption process and membrane process are similar with about $10 \%$ loss in the plant efficiency (Wang et al., 2017). For natural gas power plant with $85 \% \mathrm{CO}_{2}$ capture using amine, efficiency of the integrated plant decreases by over $8 \%$ due to the energy penalty of $\mathrm{CO}_{2}$ capture (Tock and Maréchal, 2014). Amine absorption process is difficult to use in mobile applications, although it has been proposed in marine application (Luo and Wang, 2017). Pressure swing adsorption (PSA) is well established gas separation technology, which has found applications in air separation, hydrogen purification, and natural gas industry. Further, temperature swing adsorption (TSA) is an attractive technology for $\mathrm{CO}_{2}$ capture that requires low grade waste heat which may be available close to the $\mathrm{CO}_{2}$ emission source (See Figure 2). In a TSA cycle, cooled exhaust gases are passed through the adsorbent bed, where $\mathrm{CO}_{2}$ is adsorbed in the material and the remaining gases are released into the environment. Once adsorbent bed is saturated with $\mathrm{CO}_{2}$, it is heated to recover the $\mathrm{CO}_{2}$ from the material. After $\mathrm{CO}_{2}$ recovery from the adsorbent bed, it is cooled down from the desorption temperature to the adsorption temperature. Note that heat is removed during adsorption step, whereas heat is supplied during desorption step of a TSA cycle.

The temperature of engine exhaust normally range from 350 to $700^{\circ} \mathrm{C}$ (Dimitrova and Maréchal, 2017; Kanchibhotla and Bari, 2018). Further, the heat of cooling system can also be recovered as around $95^{\circ} \mathrm{C}$ (Abdelghaffar et al., 2002). The waste heat from engine exhaust and cooling system has been used in Rankine cycle to generate mechanical power for heavy duty trucks (Grelet et al., 2016) and cruise ships (Luo and Wang, 2017). Sprouse and Depcik (2013) have reviewed many studies on the use of organic Rankine cycle for the waste heat recovery from the exhaust of internal combustion engine, and claimed $10 \%$ improvement in the fuel economy. In order to overcome the dynamic nature of the engine waste heat availability, a heat storage material can be used to maintain the steady supply of heat to the Rankine cycle

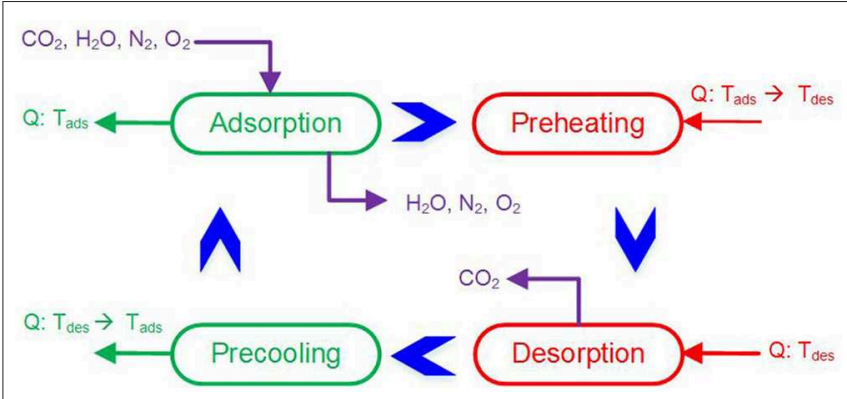

FIGURE 2 | Simple schematic of TSA cycle with four steps. Q, Heat Supplied or Removed; $T_{a d s}$, Absorption Temperature; $T_{\text {des }}$, Desorption temperature.
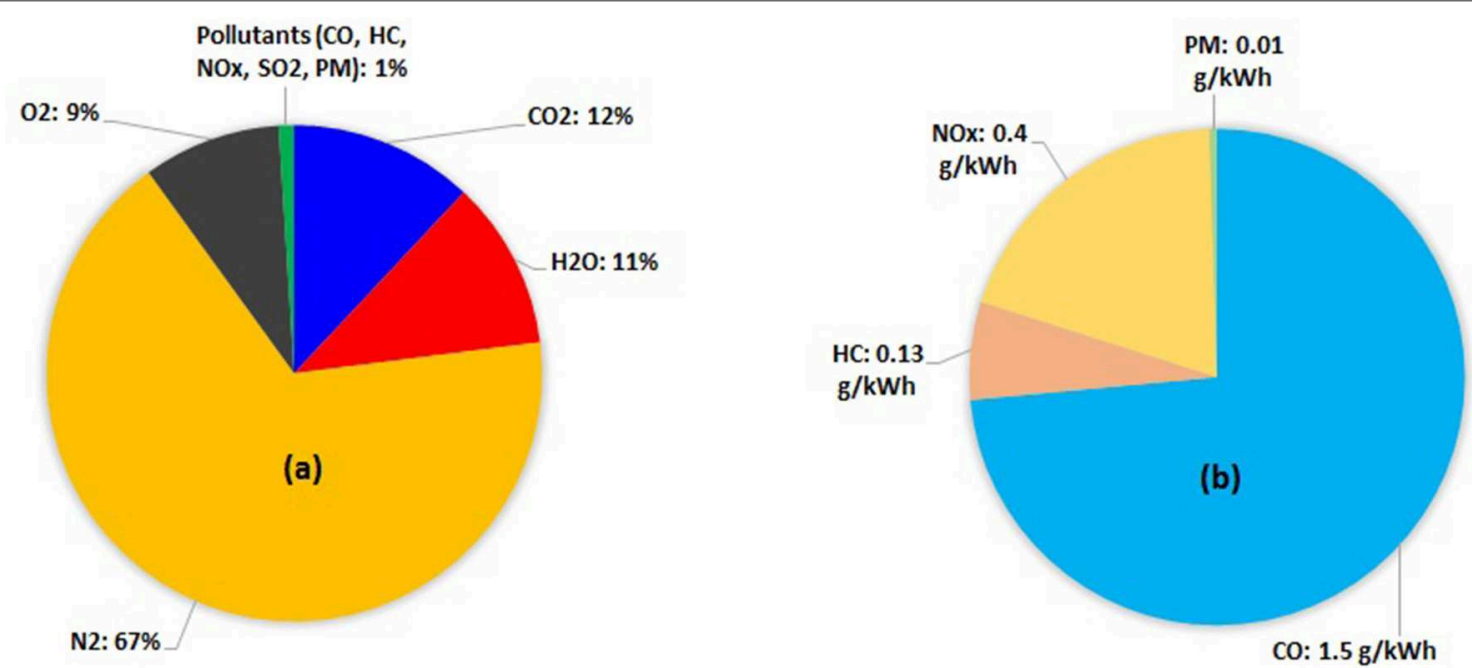

FIGURE 1 | (a) Composition of exhaust gas from diesel engine; (b) Euro emissions standard for heavy duty vehicles. 
(Dinker et al., 2017). Lu et al. (2017) used a thermal fluid for the heat transfer between engine exhaust stream and working fluid of organic Rankine cycle, this mechanism is useful in maintaining steady operation of organic Rankine cycle.

The idea of the study is to investigate the possibility of integrating a Rankine cycle and a temperature swing adsorption system for vehicles. Proll et al. (2016) evaluated a fluidized bed TSA system for $\mathrm{CO}_{2}$ capture from flue gas stream, and in terms of heat transfer, fluidized bed reactor was found better than fixed, and moving bed reactors. Gibson et al. (2016) have evaluated several adsorption materials and process designs for $\mathrm{CO}_{2}$ capture from gas fired power plant. They have developed an adsorption model to predict the separation efficiency and to obtain the optimum separation conditions. Ntiamoah et al. (2016) performed cyclic experiments on single adsorption column, and product (hot) $\mathrm{CO}_{2}$ was used to supply the heat of desorption in the desorption step. In order to increase the purity of product $\mathrm{CO}_{2}$, they used product $\mathrm{CO}_{2}$ purge before the desorption step. Marx et al. (2016) studied cyclic behavior and separation performance of TSA for post-combustion $\mathrm{CO}_{2}$ capture. They performed break-through, heating and cooling, and steadystate cyclic experiments to evaluate separation performance of the process.

This work combines organic Rankine cycle with TSA to capture the $\mathrm{CO}_{2}$ from exhaust stream of an internal combustion engine. Amine doped adsorbents are selected for $\mathrm{CO}_{2}$ capture, as they show good performance in the presence of water (Huck et al., 2014). Part of the mechanical power produced by organic Rankine cycle is used to generate cold utility using $\mathrm{CO}_{2}$-based heat pump (turbo-compressor 1). This cold utility is used to remove heat of adsorption, and condense the water from engine exhaust stream. The remaining mechanical power generated by organic Rankine cycle is used to compress and liquefy the produced $\mathrm{CO}_{2}$ (turbo-compressor 2). The $\mathrm{CO}_{2}$ capture system has energy self-sufficiency, and does not require any external power. In other words, TSA with turbo-compressors is an attractive choice for $\mathrm{CO}_{2}$ capture from vehicles without any energy penalty. The $\mathrm{CO}_{2}$ capture system for engine exhaust stream aims at capturing $90 \%$ of the emitted $\mathrm{CO}_{2}$ (i.e., $2.11 \mathrm{~kg}$ $\mathrm{CO}_{2}$ per liter of diesel consumption). The captured $\mathrm{CO}_{2}$ can be utilized as a carbon source for producing green fuel (methane or liquid fuels) by integrating hydrogen produced from renewable energy resources.

\section{ENERGY AND EXERGY BALANCE OF ENGINE, TSA AND $\mathrm{CO}_{2}$ COMPRESSION}

Figure 3 describes the integrated $\mathrm{CO}_{2}$ capture system, based on 11 diesel consumption in an internal combustion engine. First of all, diesel engine exhaust is analyzed for energy content and its composition. Figure 3 shows simple heat and mass flows for $\mathrm{CO}_{2}$ capture system. One liter diesel contains 37.27 MJ energy (lower heating value), which is divided into

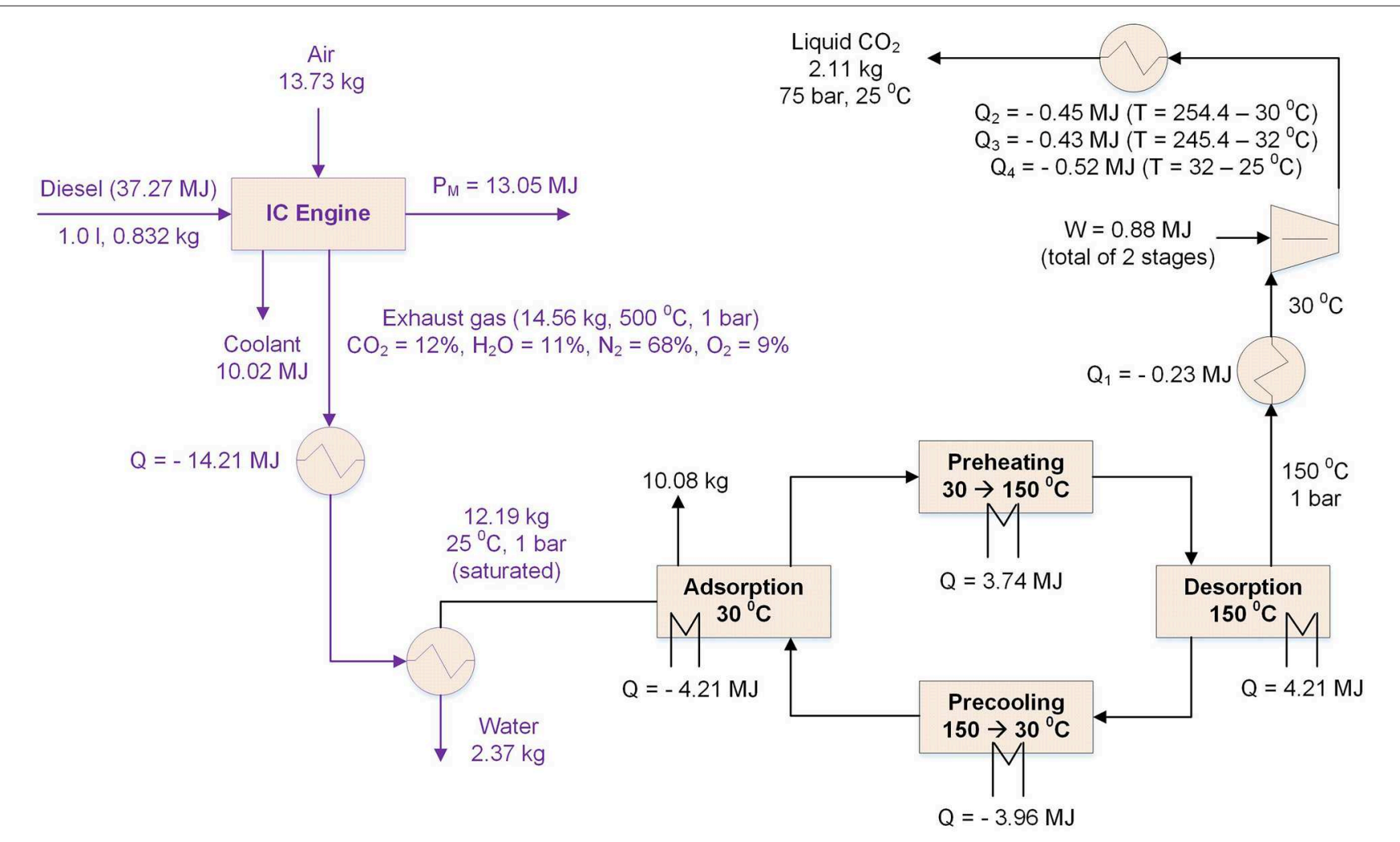

FIGURE 3 | Simple heat and mass flows for $\mathrm{CO}_{2}$ capture from diesel engine exhaust: exhaust cooling, TSA cycle, product $\mathrm{CO}_{2}$ compression, and liquefaction. 

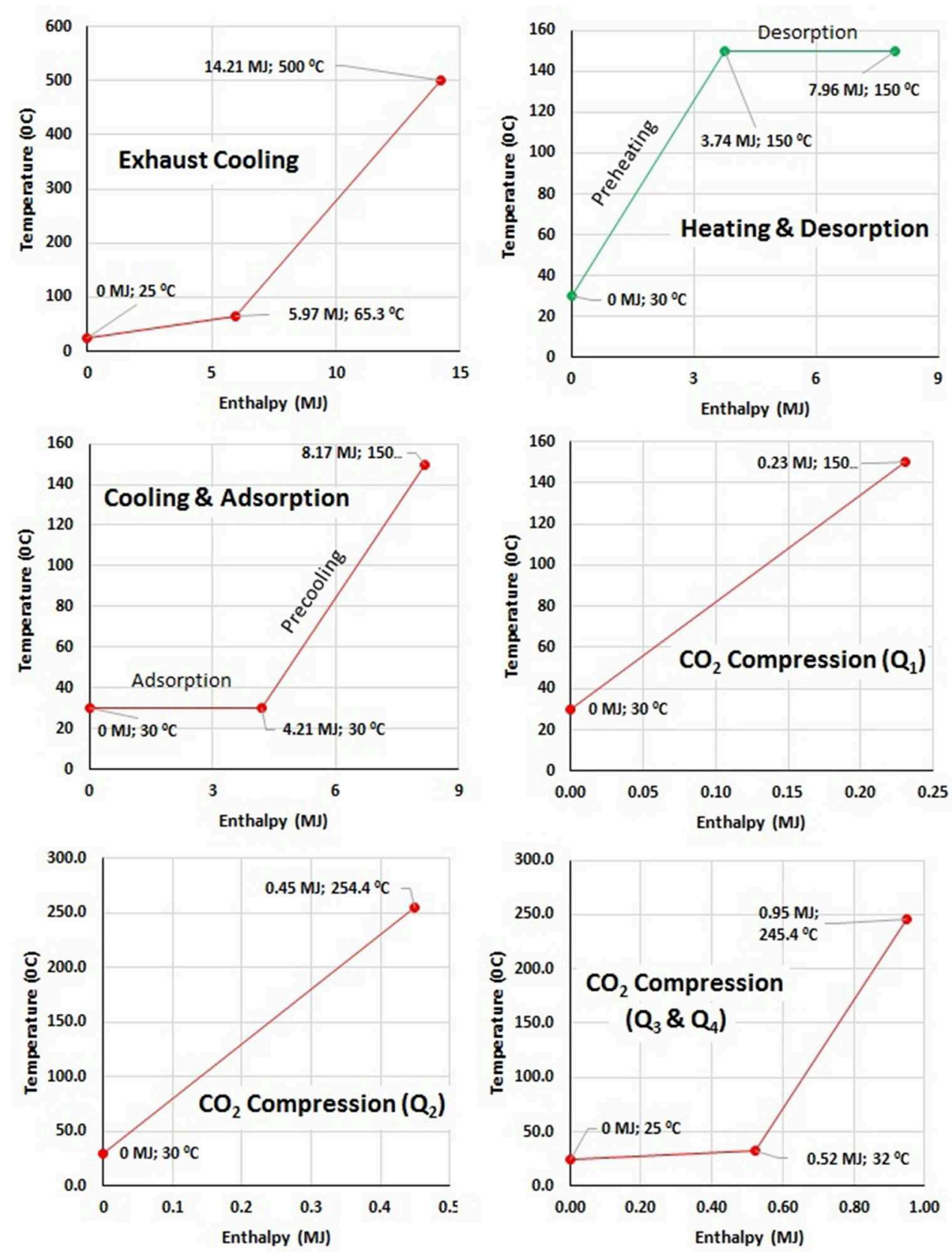

FIGURE 4 | Enthalpy-temperature profiles for exhaust cooling, adsorption cooling, desorption heating and $\mathrm{CO}_{2}$ compression, and liquefaction for 1 I diesel.

three parts by the internal combustion engine: 13.05 MJ as mechanical power to drive the vehicle, $14.21 \mathrm{MJ}$ as waste heat in exhaust gas, and $10.02 \mathrm{MJ}$ as heat removed using coolant (Hossain and Bari, 2014).

The exhaust gas stream is cooled down to $25^{\circ} \mathrm{C}$, and water is condensed and removed. The cooled exhaust gas stream (saturated with water at $25^{\circ} \mathrm{C}$ ) goes to the adsorption bed, where $\mathrm{CO}_{2}$ is attached to the adsorbent. Finally, $\mathrm{CO}_{2}$ is desorbed from the adsorbent at high temperature, and then compressed and liquefied (multi-stage compression with inter-stage cooling). After desorption step, adsorbent bed is cooled down so that it can be used in the next TSA cycle. Belsim Vali models were developed for exhaust cooling and $\mathrm{CO}_{2}$ compression with inter-stage coolers. These models compute heat available from the exhaust stream at different temperature levels, and total compression power and inter-stage cooling requirements for $\mathrm{CO}_{2}$ compression. A TSA model was developed in gPROMS process simulator, 
based on the mathematical model shown in Table B of Supplementary Material (Casas et al., 2013). The TSA model has adsorption, preheating, desorption, and precooling steps. A mixture of $\mathrm{N}_{2}(84 \%)$ and $\mathrm{CO}_{2}(16 \%)$ was used to calculate heat of desorption, preheating of bed, heat of desorption and precooling of bed, at different adsorption, and desorption temperatures. The developed TSA model uses PPN-6- $\mathrm{CH}_{2}$ TETA (Table C in Supplementary Material; Huck et al., 2014) as an adsorbent material. Finally, adsorption temperature of $30^{\circ} \mathrm{C}$ and desorption temperature of $150^{\circ} \mathrm{C}$ were chosen (see Figure A in Supplementary Material).

Figure 4 shows enthalpy-temperature profiles for exhaust cooling, heating and desorption of adsorbent, cooling and adsorption of adsorbent, and product $\mathrm{CO}_{2}$ compression and liquefaction. The exhaust stream contains $14.21 \mathrm{MJ} / \mathrm{l}$-diesel waste heat, heating and desorption step requires $7.96 \mathrm{MJ} / \mathrm{l}$-diesel heat, $8.17 \mathrm{MJ} / \mathrm{l}$-diesel heat has to be removed during cooling and adsorption step, and $1.63 \mathrm{MJ} / \mathrm{l}$-diesel heat has to be removed for $\mathrm{CO}_{2}$ compression and liquefaction.

Table 1 presents energetic and exergetic analyses of an internal combustion engine, TSA and $\mathrm{CO}_{2}$ compression and liquefaction (Al-Najem and Diab, 1992; Kul and Kahraman, 2016). The $\mathrm{CO}_{2}$ capture system design looks feasible from the exergetic point of view (Table 1 and Figure 5). In total, $3.04 \mathrm{MJ}$ of net exergy is available. See the Supplementary Material for Exergy Calculations given in Table 1. In reality, this system is dynamic in nature due to exhaust variations and TSA cycle. The reported exergy analysis is for steady-state operation of the system which gives indication on the heat availability and heat requirements by the system. Assuming a 50\% exergy efficiency, therefore there is a potential to produce the equivalent of $1.52 \mathrm{MJ}$ of mechanical power for the $\mathrm{CO}_{2}$ capture and storage system. Assuming an isentropic efficiency of $75 \%$ for the compressors, this value can be compared with the compression power needed to produce $\mathrm{CO}_{2}$ in the liquid form (compression at $75 \mathrm{bar}$ ): $0.88 \mathrm{MJ}$ or compressed $\mathrm{CO}_{2}$ at 150 bar: $1.05 \mathrm{MJ}$. For 11 diesel consumption in an internal combustion engine, $2.11 \mathrm{~kg} \mathrm{CO}_{2}$ is captured by the system, which has a volume of 2.961 as liquid $\mathrm{CO}_{2}$ product (at 75 bar) or 4.531 as compressed $\mathrm{CO}_{2}$ product (at 150 bar).

\section{DESIGN OF $\mathrm{CO}_{2}$ CAPTURE SYSTEMS FOR A DELIVERY TRUCK}

The preliminary exergy analysis shows that there is the opportunity by system integration to generate cold, heat, and work that is needed to capture the exhaust $\mathrm{CO}_{2}$ using the energy available in the exhaust gases. Referring to the usage in a mobile application, there is a need to generate cooling for adsorption step, and therefore production of cooling capacity is considered at a temperature lower than the $40^{\circ} \mathrm{C}$. The overall system design concept combines exhaust cooling, TSA cycle, product $\mathrm{CO}_{2}$ compression and cooling, Rankine cycle and heat pumping, as shown in Figure 6.

The $\mathrm{CO}_{2}$ capture system is designed for 1 day operation of delivery truck in a city, which travels $250 \mathrm{~km}$ in $8 \mathrm{~h}(\sim 201$ diesel/100 km, Delgado et al., 2017). The diesel engine emits
TABLE 1 | Energy and exergy analyses of the internal combustion engine, the $\mathrm{CO}_{2}$ capture system, and compression power required for $\mathrm{CO}_{2}$ liquefaction (1 I diesel).

\begin{tabular}{|c|c|c|c|c|}
\hline Internal combustion engine & $\begin{array}{l}\text { Diesel } \\
\text { (fuel) }\end{array}$ & $\begin{array}{l}\text { Mechanical } \\
\text { power }\end{array}$ & Exhaust & $\begin{array}{l}\text { Cooling } \\
\text { system }\end{array}$ \\
\hline Energy, MJ & 37.27 & 13.05 & 14.21 & 10.02 \\
\hline Exergy, MJ & 38.53 & 13.05 & 3.91 & 2.42 \\
\hline $\mathrm{CO}_{2}$ capture system & Exhaust & $\begin{array}{l}\text { Heating and } \\
\text { desorption }\end{array}$ & $\begin{array}{l}\text { Cooling and } \\
\text { adsorption }\end{array}$ & $\mathrm{CO}_{2}^{*}$ \\
\hline Energy, MJ & 14.21 & 7.96 & 8.17 & 1.63 \\
\hline Exergy, MJ & 3.91 & -1.88 & 0.74 & 0.27 \\
\hline Net exergy available: $\varepsilon, \mathrm{MJ}$ & 3.04 & & & \\
\hline $\begin{array}{l}\text { Potential mechanical power } \\
\text { production }(=0.5 \varepsilon), \mathrm{MJ}\end{array}$ & 1.52 & & & \\
\hline $\begin{array}{l}\text { Mechanical power for } \mathrm{CO}_{2} \\
\text { compression ( } 75 \text { bar) and } \\
\text { liquefaction, } \mathrm{MJ}\end{array}$ & 0.88 & & & \\
\hline $\begin{array}{l}\text { Mechanical power for } \mathrm{CO}_{2} \\
\text { compression (150 bar), MJ }\end{array}$ & 1.05 & & & \\
\hline
\end{tabular}

*Includes heat removed by $Q_{1}, Q_{2}, Q_{3}$, and $Q_{4}$ heat exchangers in Figures 3, 4. Detailed exergy calculations are shown in the Supplementary Material.

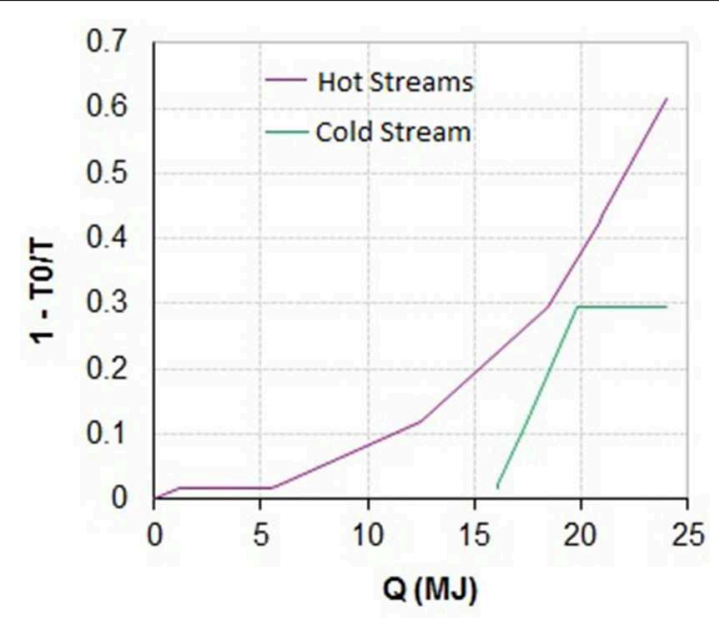

FIGURE 5 | Q vs. 1-T0/T plot for $\mathrm{CO}_{2}$ capture system (1 I diesel); T0 (reference temperature) $=298 \mathrm{~K}$.

$117.2 \mathrm{~kg}$ of $\mathrm{CO}_{2}$ by consuming $50 \mathrm{l}$ diesel, and $105.5 \mathrm{~kg}$ of $\mathrm{CO}_{2}$ ( $90 \%$ capture) should be captured and stored by the $\mathrm{CO}_{2}$ capture system. The working capacity (or $\mathrm{CO}_{2}$ loading) of the adsorbent material is $0.1 \mathrm{~kg}-\mathrm{CO}_{2} / \mathrm{kg}$-adsorbent (Verdegaal et al., 2016). Finally, $1 \mathrm{~h}$ adsorption-desorption cycle time has been assumed (Gibson et al., 2016). Initially, three cases for $\mathrm{CO}_{2}$ capture system are analyzed, as summarized in Table 2.

\section{Adsorption on Truck and Desorption in the Parking Lot}

In total, $105.5 \mathrm{~kg}$ of $\mathrm{CO}_{2}$ should be captured by the adsorbent. It requires $1055 \mathrm{~kg}$ of adsorbent, with $\mathrm{CO}_{2}$ loading of 0.1 


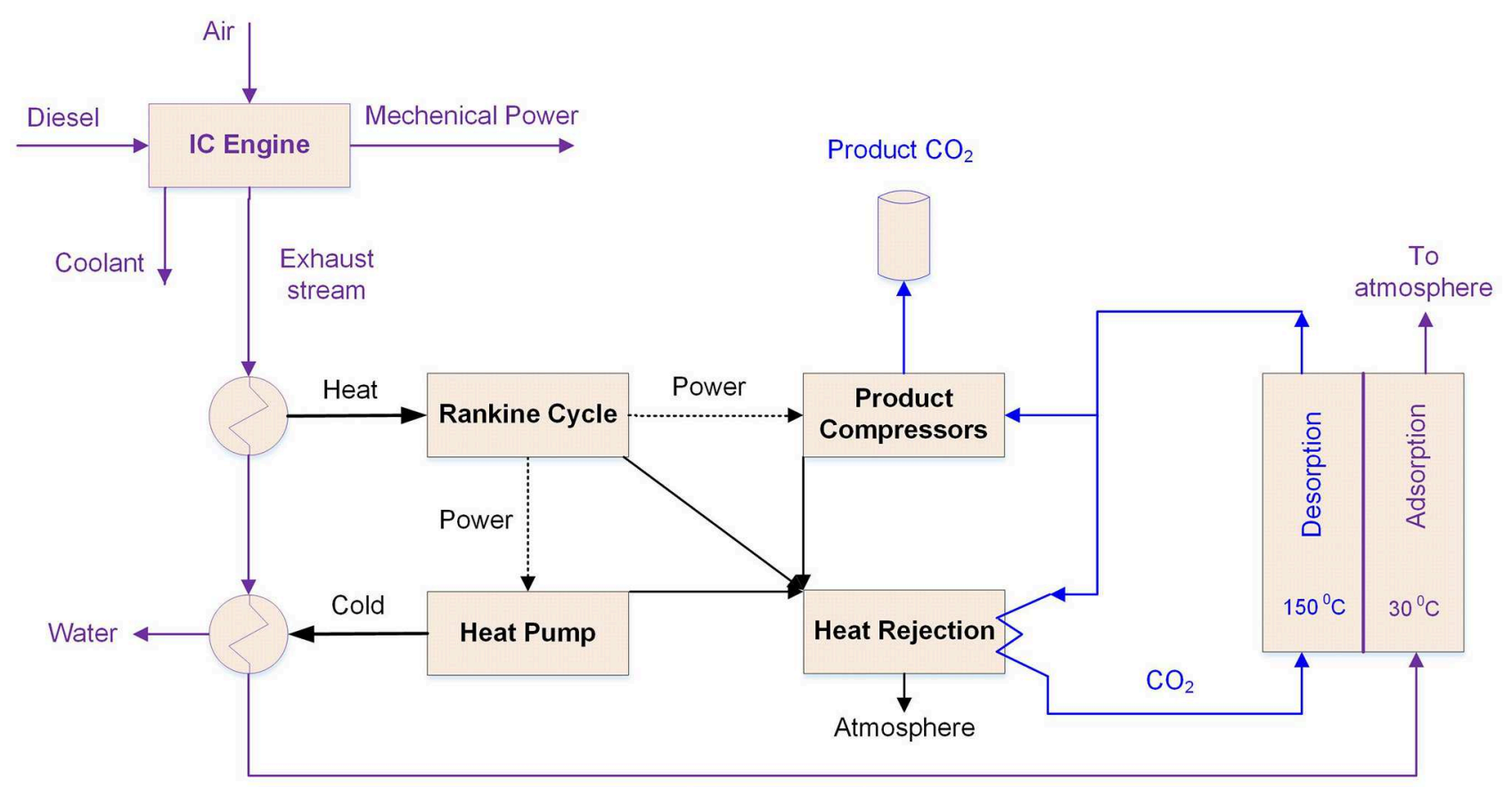

Cold exhaust stream

FIGURE 6 | Overview of $\mathrm{CO}_{2}$ capture system design: integration of Rankine cycle (RC) and heat pump (HP).

TABLE 2 | Details of $\mathrm{CO}_{2}$ capture system specification (1 day operation, $250 \mathrm{~km}$ travel, 50 I diesel consumptions).

\begin{tabular}{|c|c|c|c|c|c|c|c|c|}
\hline Case & $\begin{array}{l}\text { Storage P } \\
\text { (bar) } \mathrm{T}\left({ }^{\circ} \mathrm{C}\right)\end{array}$ & $\begin{array}{l}\mathrm{CO}_{2} \text { mass } \\
(\mathrm{kg})\end{array}$ & $\begin{array}{l}\mathrm{CO}_{2} \text { volume } \\
\text { (liter) }\end{array}$ & $\begin{array}{l}\text { Adsorbent mass } \\
\quad(\mathrm{kg})\end{array}$ & $\begin{array}{c}\text { Adsorbent } \\
\text { volume (liter) }\end{array}$ & $\begin{array}{l}\text { Tank mass } \\
(\mathbf{k g})\end{array}$ & $\begin{array}{l}\text { Total mass } \\
(\mathbf{k g})\end{array}$ & $\begin{array}{c}\text { Total volume } \\
\text { (liter) }\end{array}$ \\
\hline 1 & & 105.7 & & 1,055 & 1310.6 & & 1160.5 & 1310.6 \\
\hline \multirow[t]{3}{*}{3} & 75,32 & 105.7 & 811.11 & $4 \times 32.97$ & $4 \times 40.95$ & 584.0 & 821.4 & 974.9 \\
\hline & 100, 32 & 105.7 & 226.41 & $4 \times 32.97$ & $4 \times 40.95$ & 163.0 & 400.4 & 390.2 \\
\hline & 150, 32 & 105.7 & 226.41 & $4 \times 32.97$ & $4 \times 40.95$ & 163.0 & 400.4 & 390.2 \\
\hline
\end{tabular}

$\mathrm{kg}-\mathrm{CO}_{2} / \mathrm{kg}$-adsorbent. Hence, the total mass of the system is $1160.5 \mathrm{~kg}$. The density of adsorbent is $0.805 \mathrm{~kg} / \mathrm{liter}$, and so the volume of adsorbent or capture system is 1310.6 l. In the parking lot, $\mathrm{CO}_{2}$ can be converted into methane, and exothermic heat of methanation reaction can be used to recover $\mathrm{CO}_{2}$ from the adsorbent bed.

\section{Adsorption-Desorption on Truck With $\mathrm{CO}_{2}$ Liquefaction (Liquid $\mathrm{CO}_{2}$ )}

In this case, $\mathrm{CO}_{2}$ is captured, compressed, liquefied, and stored in a storage tank. The critical point of $\mathrm{CO}_{2}$ is $31.1^{\circ} \mathrm{C}$ and 73.8 bar. In order to store liquid $\mathrm{CO}_{2}$ around $25^{\circ} \mathrm{C}$ in summer, an efficient cooling system would be required for operation of $\mathrm{CO}_{2}$ capture and storage system. The diesel engine consumes 6.251 diesel per hour that means $13.19 \mathrm{~kg} \mathrm{CO}_{2}$ should be captured per hour (11 diesel $=2.34 \mathrm{~kg} \mathrm{CO}_{2}$ emission, $90 \%$ $\mathrm{CO}_{2}$ capture, see Figure 3). Hence, the $\mathrm{CO}_{2}$ capture system requires $131.88 \mathrm{~kg} / \mathrm{h}(163.8 \mathrm{l} / \mathrm{h})$ of adsorbent. The duration of a TSA cycle is $1 \mathrm{~h}$, and the regenerated adsorbent material can be used in the next TSA cycle. The estimated mass of storage tank is $273.6 \mathrm{~kg}$ to store $105.5 \mathrm{~kg}$ (or 147.961) liquid $\mathrm{CO}_{2}$ at 75 bar and $25^{\circ} \mathrm{C}$ (Turton et al., 2012). Further, typical weight of storage tank (modified CrMo steel) is $0.72 \mathrm{~kg} / \mathrm{liter}$ for compressed natural gas at 200 bar (Ashok Leyland Report, 2012), and this light weight tank can also be used to store liquid or compressed $\mathrm{CO}_{2}$.

gPROMS model was developed for TSA cycle, whereas Belsim Vali models were developed for exhaust cooling, $\mathrm{CO}_{2}$ compression with inter-stage cooling, Rankine cycle and heat pump. $\mathrm{CO}_{2}$ based Rankine cycle (160 and 75 bar) is used to extract heat from the exhaust gas stream, and to produce the mechanical power in a turbine. This mechanical power is used in $\mathrm{CO}_{2}$ based heat pump (75 and 50 bar) to generate cold utility for removing heat of adsorption from bed and precooling of bed from desorption temperature to adsorption temperature. The 
lower pressure level for Rankine cycle and upper pressure level for heat pump are same (75 bar), so that streams from Rankine cycle and heat pump cycle can be combined for discharging waste heat into the environment. Figure 7 shows integrated operations of $\mathrm{CO}_{2}$ based Rankine cycle and heat pump. Further, heat rejected from $\mathrm{CO}_{2}$ based Rankine cycle is used for supplying heat of desorption and preheating of bed from adsorption temperature to desorption temperature. Finally, compressors are used to compress the product $\mathrm{CO}_{2}$ after the desorption step. The mechanical power generated using turbine is sufficient to run compressor for $\mathrm{CO}_{2}$ based heat pump and compressors for product $\mathrm{CO}_{2}$.

In order to perform heat integration of the system, heat cascade model (Maréchal and Kalitventzeff, 1998) was used for heat integration among TSA cycle, exhaust cooling, interstage heat exchangers/coolers for $\mathrm{CO}_{2}$ compression, Rankine cycle, and heat pump. Figure 8 presents composite and grand composite curves for cooling of exhaust gas stream, heat of

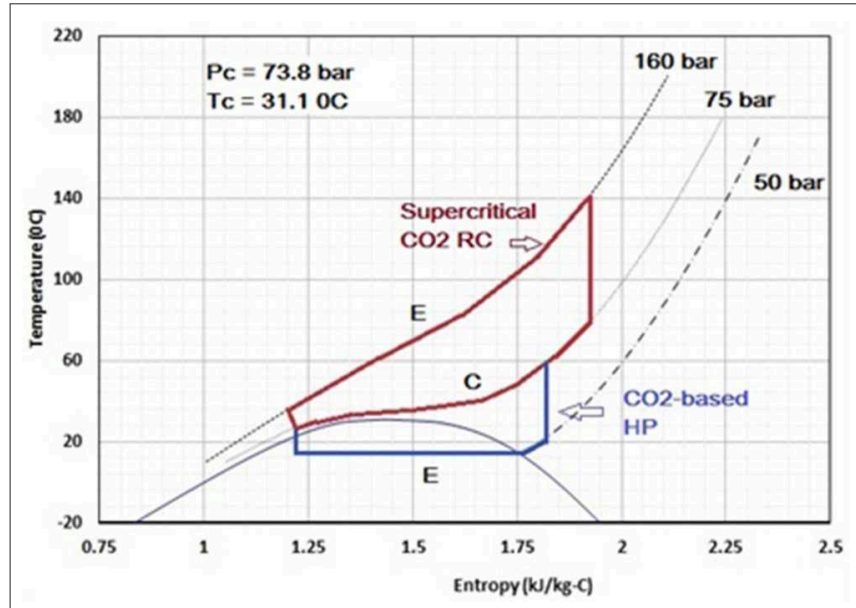

FIGURE 7 | Integrated operation of $\mathrm{CO}_{2}$-based Rankine cycle $(\mathrm{RC})$ and heat pump (HP). adsorption and precooling, heat of desorption and preheating, $\mathrm{CO}_{2}$ based Rankine cycle and heat pump, and product $\mathrm{CO}_{2}$ compression. In Figure 8, no external hot utility is required to close the heat balance which shows the feasibility of the $\mathrm{CO}_{2}$ capture system. The composite curves provides minimum energy targets (i.e., hot and cold utilities) that can be used in the heat exchanger network synthesis. Figure 9 presents a simple schematic of $\mathrm{CO}_{2}$ capture system design, without showing heat integration between hot and cold streams. In Figure 9, streams in red color show Rankine cycle operation, whereas streams in blue color show heat pump cycle operation. It can be seen that Rankine cycle and heat pump cycle streams are merged to discharge waste heat (RH1) into the environment. The product $\mathrm{CO}_{2}$ stream from desorption step is shown in green color, and it is compressed from 1 bar to 50 bar, before merging with heat pump cycle. The product $\mathrm{CO}_{2}$ is removed from the heat pump cycle at 75 bar and $30^{\circ} \mathrm{C}$. Alternatively, a separate product $\mathrm{CO}_{2}$ compression and liquefaction system is also possible. The purity of product $\mathrm{CO}_{2}$ has been calculated using adsorbed phase $\mathrm{CO}_{2}$ and bulk phase gas mixture (i.e., cooled exhaust gas) inside the adsorption bed. The purity of product $\mathrm{CO}_{2}$ is about $99.5 \%$, assuming $40 \%$ inter-particle empty space.

In order to achieve the target temperatures of hot and cold streams with minimum utilities, hot and cold streams should exchange heat whenever possible. In this work, the heat exchanger network synthesis (stage-wise superstructure model) has been studied by mathematical programming method. For this, a mixed integer linear programming (MILP) optimization problem, written in AMPL, has been solved using CPLEX solver (Yee and Grossmann, 1990; Mian et al., 2016). In the optimization problem, minimization of number of heat exchangers is considered as objective function. There are 11 hot streams (AD1, AD2, EE1, EE2, RC4, RH1, HP3, HP4, CC1, $\mathrm{CC} 2$, and CC3) and 7 cold streams (DE1, DE2, RC1, RC2, RC3, $\mathrm{HP} 1$, and HP2) in the $\mathrm{CO}_{2}$ capture system. Table 3 presents heat exchanger network synthesis results, which has 20 heat exchangers. See Supplementary Material for grid representation

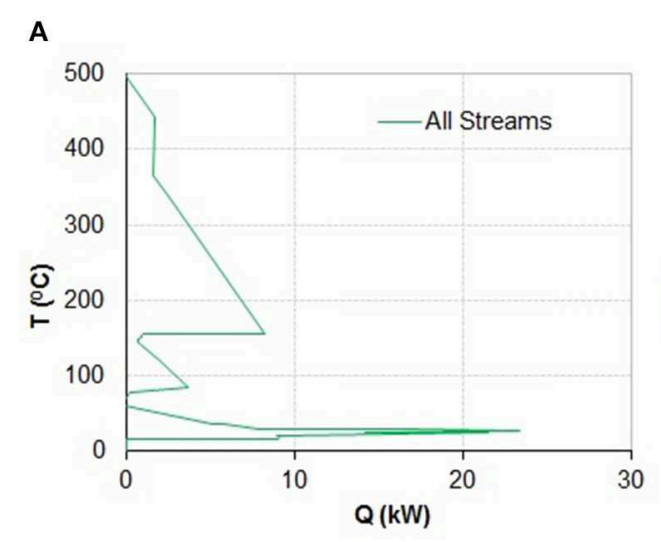

B

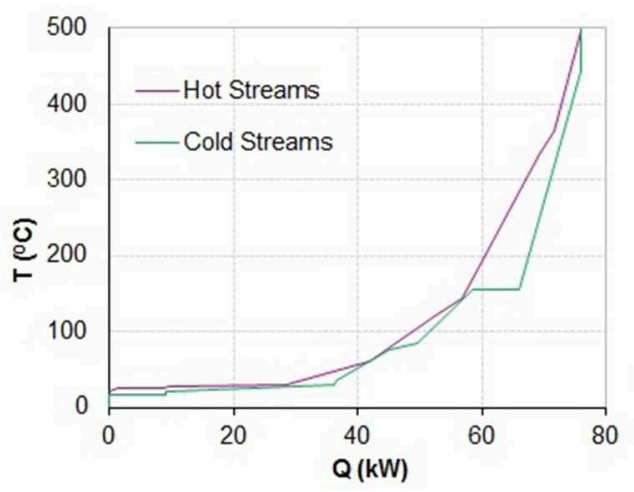

FIGURE 8 | Grand composite (A) and composite (B) curves for the $\mathrm{CO}_{2}$ capture system. 


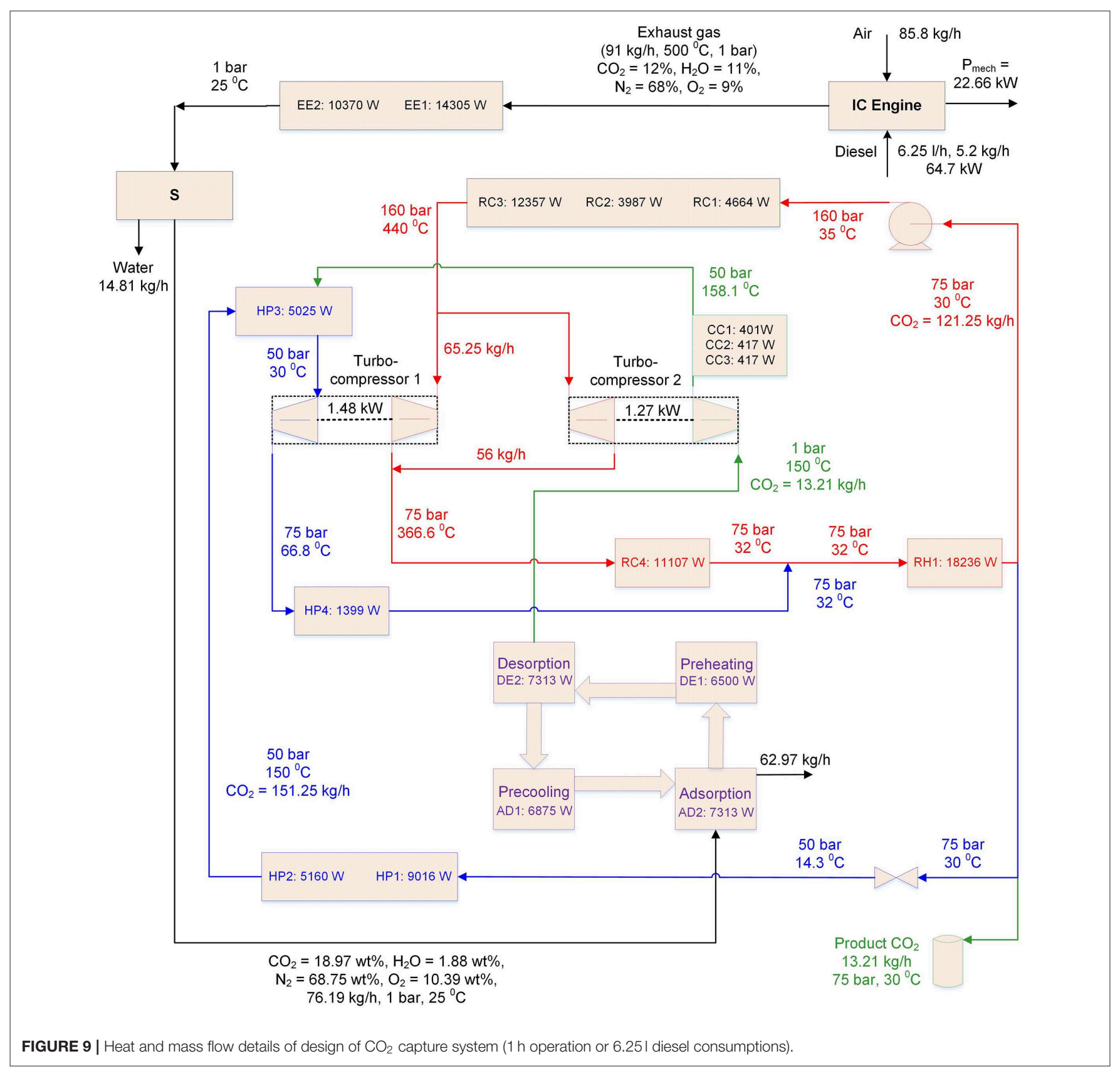

of HEN. In Table 3, overall heat transfer coefficient (U) for a heat exchanger, with low heat transfer coefficients streams (exhaust cooling, precooling, adsorption, preheating and desorption), is assumed to be $25 \mathrm{~W} /\left(\mathrm{m}^{2} . \mathrm{K}\right)$ (Clausse et al., 2011; Ribeiro et al., 2013; Marx et al., 2016). Further, the $U$-value for a heat exchanger, with high heat transfer coefficients streams (Rankine cycle, heat pump and cooling utility), is assumed to be $2000 \mathrm{~W} /\left(\mathrm{m}^{2} . \mathrm{K}\right)$ (Yang, 2016). Finally, $U$-value of 500 $\mathrm{W} /\left(\mathrm{m}^{2} \mathrm{~K}\right)$ is assumed for a heat exchanger with one low heat transfer coefficient stream and other high heat transfer coefficient stream. Table 3 presents estimated heat transfer areas for different heat exchanges, and AD1-DE1 heat exchanger (precooling and preheating of adsorption bed) has largest heat transfer area $\left(11.23 \mathrm{~m}^{2}\right)$. Total heat transfer area of all heat exchangers is $22.47 \mathrm{~m}^{2}$. More accurate heat exchanger area may be calculated by estimating overall heat transfer coefficients for different streams/heat exchangers. This heat transfer area can be provided in compact volume by using microchannel heat exchangers, wherever it is possible (Hesselgreaves, 2001). TSA is a cyclic process with four steps, and so the heat exchangers inside the adsorbent beds should be heated and cooled in a cyclic way. Hence, heating and cooling of heat exchangers material will increase the thermal duty of the system. 


\section{Adsorption-Desorption on Truck With $\mathrm{CO}_{2}$ Compression (Compressed $\mathrm{CO}_{2}$ )}

In this case, product $\mathrm{CO}_{2}$ is compressed and stored at high pressure. The mass of compressed $\mathrm{CO}_{2}$ storage tank is much higher compared to the mass of storage tank for liquid $\mathrm{CO}_{2}$ (in Case 2). This case is suitable when compressed methane or natural gas is used as a fuel in the vehicle. Fuel tank for compressed fuel can also be used to store the compressed product $\mathrm{CO}_{2}$. Three pressures for storing compressed $\mathrm{CO}_{2}$ are considered: 75, 100, and 150 bar. It can be noted in Table 2 that compressed $\mathrm{CO}_{2}$ volume at 75 bar (811.111) is significantly larger when compared at 100 and 150 bar (226.41 l). The mass of storage tanks, for storing compressed $\mathrm{CO}_{2}$ at different pressures, are calculated as function of $\mathrm{CO}_{2}$ volume $(0.72 \mathrm{~kg} / \mathrm{liter}$; Ashok Leyland Report, 2012). Compressed $\mathrm{CO}_{2}$ storage at 100 or 150 bar found to be better (lowest weight and volume) compared to 75 bar.

The $\mathrm{CO}_{2}$ capture system design in Case 2 (i.e., adsorptiondesorption on truck with liquid $\mathrm{CO}_{2}$ product) is an attractive choice due to its lower weight and lower volume. For daily operation of a delivery truck, the total mass and volume of the adsorbent beds and captured $\mathrm{CO}_{2}$ with storage tank are about $343.9 \mathrm{~kg}$ and $311.8 \mathrm{l}$. Additionally, some weight and space will be required for piping, turbo-compressors and heat exchanger network. In general, about $2 \mathrm{~m}^{3}$ space is available over the truck cabin (www.uhaul.com). Hence, temperature swing adsorption based $\mathrm{CO}_{2}$ capture system can easily be placed over the truck cabin. Figure $\mathrm{C}$ in Supplementary Material presents estimated volume of $\mathrm{CO}_{2}$ capture and storage system for delivery truck. The $\mathrm{CO}_{2}$ storage tank can be placed below the truck cabin, so that it can easily be removed and replaced.

\section{GREEN FUEL PRODUCTION AND USE OF ALTERNATE FUELS}

The captured $\mathrm{CO}_{2}$ by the system can be sequestrated in underground or used as feedstock to produce gas or liquid green

TABLE 4 | Use of alternate fuels in the delivery truck for $250 \mathrm{~km}$ travel.

\begin{tabular}{|c|c|c|c|c|c|}
\hline & Methane & Methanol & DME & Gasoline & $\mathrm{H}_{2}$ \\
\hline Fuel used, $\mathrm{kg}$ & 37.7 & 94.7 & 65.2 & 43.4 & 13.3 \\
\hline $\mathrm{CO}_{2}$ produced, $\mathrm{kg}$ & 103.7 & 130.2 & 124.8 & 134.1 & - \\
\hline $\mathrm{CO}_{2}$ captured $(90 \%), \mathrm{kg}$ & 93.3 & 117.2 & 112.3 & 120.7 & - \\
\hline Adsorption material required & 116.6 & 146.5 & 140.4 & 150.9 & - \\
\hline Weight of $\mathrm{CO}_{2}$ storage tank & $94.2(0)$ & 118.3 & 113.4 & 121.9 & - \\
\hline $\begin{array}{l}\text { Fuel produced using } \\
\text { captured } \mathrm{CO}_{2}, \mathrm{~kg}\end{array}$ & 34.4 & 78.2 & 52.1 & 31.0 & - \\
\hline $\begin{array}{l}\text { Fuel produced for } 90 \% \mathrm{CO}_{2} \\
\text { capture rate / fuel used }\end{array}$ & 0.90 & 0.83 & 0.80 & 0.71 & 1.0 \\
\hline $\begin{array}{l}\text { Energy content of fuel } \\
\text { produced, MJ }\end{array}$ & 1719.6 & 1555.6 & 1505.6 & 1346.2 & 1,885 \\
\hline $\begin{array}{l}\text { Renewable energy } \\
\text { consumed in fuel production, } \\
\text { MJ }\end{array}$ & 2284.2 & 2404.1 & 2396.3 & 2268.9 & 2356.3 \\
\hline Electricity to fuel efficiency, \% & 75.3 & 64.7 & 62.8 & 59.3 & 80 \\
\hline$\checkmark$ panels area & 660.9 & 695.6 & 693.4 & 656.5 & 81 \\
\hline
\end{tabular}

(Switzerland), $\mathrm{m}^{2}$

TABLE 3 | Heat exchanger network synthesis for $\mathrm{CO}_{2}$ capture system.

\begin{tabular}{|c|c|c|c|c|c|c|c|c|c|}
\hline HE name & $\begin{array}{l}\text { Duty } \\
\text { [W] }\end{array}$ & $\begin{array}{l}\text { Hot } \\
\text { stream }\end{array}$ & $\begin{array}{l}T_{h, \text { in }} \\
{[K]}\end{array}$ & $\begin{array}{l}T_{h, \text { out }} \\
{[K]}\end{array}$ & $\begin{array}{l}\text { Cold } \\
\text { stream }\end{array}$ & $\begin{array}{l}\mathbf{T}_{\mathrm{c}, \text { in }} \\
{[\mathrm{K}]}\end{array}$ & $\begin{array}{l}T_{c, \text { out }} \\
{[K]}\end{array}$ & $\begin{array}{l}\mathbf{U} \\
{\left[\mathrm{W} / \mathrm{m}^{2} . \mathrm{K}\right]}\end{array}$ & $\begin{array}{l}A \\
{\left[m^{2}\right]}\end{array}$ \\
\hline AD1-DE1 & 1,578 & AD1 & 336.99 & 309.44 & DE1 & 303 & 332.12 & 25 & 11.23 \\
\hline AD1-RC2 & 3,986 & AD1 & 423 & 353.42 & $\mathrm{RC} 2$ & 348 & 355 & 500 & 0.32 \\
\hline AD1-HP2 & 363 & AD1 & 309.44 & 303.1 & HP2 & 287.4 & 296.94 & 500 & 0.05 \\
\hline EE1-DE2 & 154 & $\mathrm{EE} 1$ & 773 & 731.58 & DE2 & 422.9 & 423 & 25 & 0.02 \\
\hline EE1-RC1 & 582 & EE1 & 356 & 338.3 & $\mathrm{RC} 1$ & 334.92 & 348 & 500 & 0.22 \\
\hline EE1-RC3 & 12,356 & EE1 & 731.58 & 356 & RC3 & 355 & 713 & 500 & 4.11 \\
\hline EE2-RC1 & 3,139 & EE2 & 338.3 & 326.09 & $\mathrm{RC} 1$ & 307.99 & 334.92 & 500 & 0.72 \\
\hline RC4-DE2 & 7,157 & $\mathrm{RC} 4$ & 639.6 & 424 & DE2 & 422.9 & 423 & 500 & 0.35 \\
\hline CC2-HP2 & 422 & $\mathrm{CC} 2$ & 427.4 & 303 & HP2 & 296.94 & 423 & 2,000 & 0.04 \\
\hline СC3-HP2 & 422 & CC3 & 427.4 & 303 & HP2 & 296.94 & 423 & 2,000 & 0.04 \\
\hline EE2-CU & 7,225 & EE2 & 326.09 & 298 & $\mathrm{CU}$ & 293 & 301 & 500 & 0.90 \\
\hline $\mathrm{RH} 1-\mathrm{CU}$ & 18,236 & $\mathrm{RH} 1$ & 305 & 303 & $\mathrm{CU}$ & 293 & 301 & 2,000 & 1.39 \\
\hline HP4-CU & 1,398 & HP4 & 339.8 & 305 & $\mathrm{CU}$ & 293 & 301 & 2,000 & 0.03 \\
\hline
\end{tabular}


fuels and chemicals. Conversion of $\mathrm{CO}_{2}$ into chemicals is a good option from economic perspective due to their high prices (Chen et al., 2018). Table D (in Supplementary Material) presents the conversion of $1 \mathrm{~kg}$ of $\mathrm{CO}_{2}$ into green fuel by co-electrolysis (solid oxide electrolysis cell) using renewable electricity (Wang et al., 2018). The renewable electricity for $\mathrm{CO}_{2}$ conversion into green fuels can be provided by the PV panels. For calculating total area of PV panels in Switzerland, $400 \mathrm{~W} / \mathrm{m}^{2}$ average annual solar irradiation (17.28 MJ/day/ $\mathrm{m}^{2}$; www.meteoswiss.admin.ch) has been considered in Table D (Supplementary Material). Further, solar irradiation to electricity conversion efficiency of $20 \%$ has been assumed for the PV panels.

The delivery truck consumes $501(41.6 \mathrm{~kg})$ diesel for $250 \mathrm{~km}$ travel, or 1,885 MJ energy based on the lower heating value of diesel fuel. Assuming same efficiency of the engine for different fuels, Table 4 presents amount of alternate fuels used, $\mathrm{CO}_{2}$ produced, $\mathrm{CO}_{2}$ captured, fuel produced using captured $\mathrm{CO}_{2}$, renewable energy consumed, and PV panel area. The fuel produced / fuel used ratio is different for different carbon based green fuels. In Table 4, $\mathrm{H}_{2}$ fuel is also reported for comparison purpose. The efficiency of electrolysis (electricity to $\mathrm{H}_{2}$ ) is assumed to be $80 \%$ (Schaaf et al., 2014), $\mathrm{H}_{2}$ efficiency in the internal combustion engine is considered same as for diesel engine (Verhelst and Wallner, 2009). In order to use $\mathrm{H}_{2}$ in existing internal combustion engine, fuel supply system has to be modified to avoid pre-ignition in the premixed $\mathrm{H}_{2}$ and air (Salvi and Subramanian, 2015). Further, high $\mathrm{NO}_{\mathrm{x}}$ emission has been reported for $\mathrm{H}_{2}$ in spark ignition engine due to increase in combustion temperature (Shivaprasad et al., 2018). Figure 10 presents weight of fuel with storage tank and $\mathrm{CO}_{2}$ capture system with liquid $\mathrm{CO}_{2}$ storage, for different fuels. For compressed $\mathrm{CH}_{4}$ fuel, it is assumed that captured $\mathrm{CO}_{2}$ can be stored in the same storage tank. For different fuels, the total weight (fuel with storage tank, adsorbent material, and $\mathrm{CO}_{2}$ with storage tank) are compared at initial point $(0 \mathrm{~km})$, mid-point $(125 \mathrm{~km})$, and end point $(250 \mathrm{~km})$. For carbon based fuels, added weights of fuel and $\mathrm{CO}_{2}$ capture and storage systems are comparable.

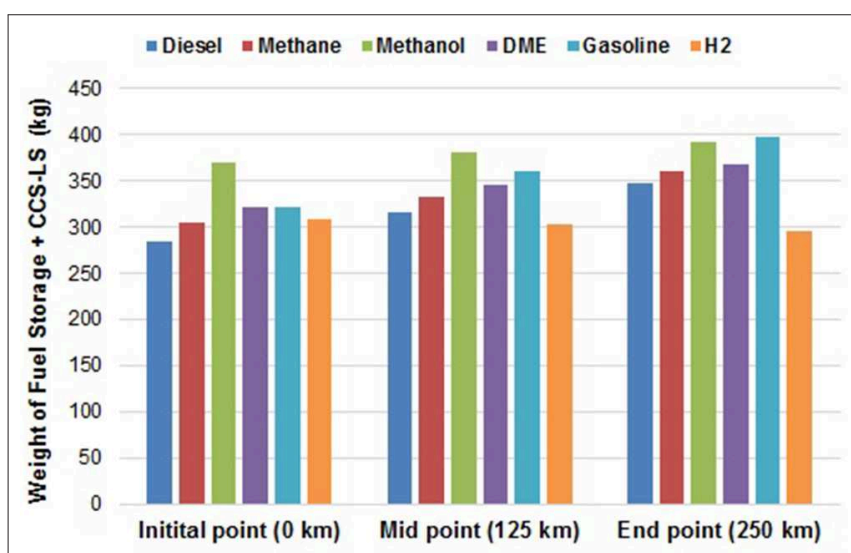

FIGURE 10 | Weight comparison between on-board storage of $\mathrm{H}_{2}$ and different carbon based fuels with CCS-LS for conventional internal combustion engine.

\section{$\mathrm{CO}_{2}$ CAPTURE SYSTEM AND LIQUID STORAGE FOR DIFFERENT VEHICLES}

The $\mathrm{CO}_{2}$ capture system and liquid storage (CCS-LS) can be integrated on different types on vehicles such as cars, trucks, buses, ships, and trains. Average weights, payloads and fuel (diesel) consumptions for different types of vehicles are reported in the Supplementary Material (Table E). The added weight of CCS-LS includes weights of $\mathrm{CO}_{2}$ with storage tank and adsorbent material. For comparison basis, each vehicle is assumed to be traveled $250 \mathrm{~km}$ (diesel fuel), and travel time for each vehicle is reported in the Supplementary Material (Table F). Figure 11 presents percentage added weight of CCS-LS with respect to total weight of vehicle (i.e., empty weight of vehicle + payload on vehicle) and payload on vehicle. For ferry and cruiseship, payloads are estimated based on maximum number of onboard persons. As expected, percentage added weight of CCSLS is larger for small vehicles (car, SUV) compared to large vehicles (ferry, cruiseship, train). CCS-LS can be used on vehicle to reduce the $\mathrm{CO}_{2}$ emissions by allowing a higher share of renewables used in the transport and reducing the fossil $\mathrm{CO}_{2}$ emissions to environment and the same time to generate cooling

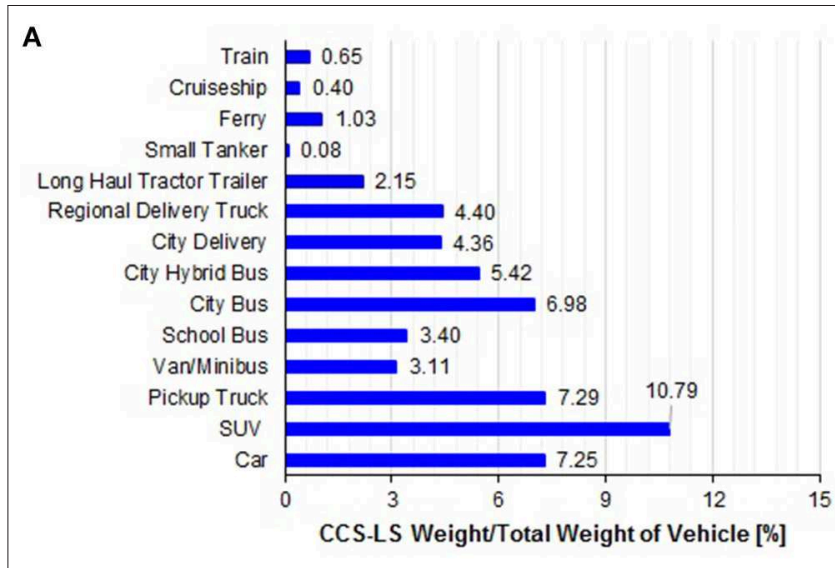

B

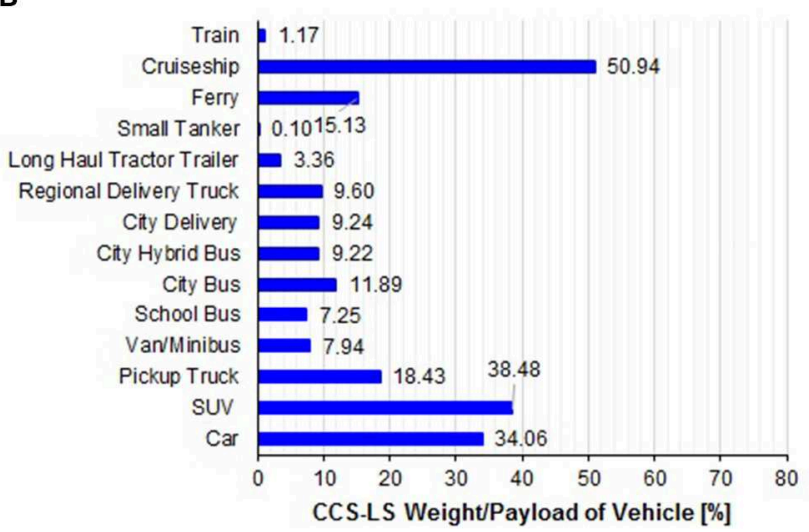

FIGURE 11 | Percentage added weight of $\mathrm{CO}_{2}$ capture system and liquid storage (CCS-LS) with respect to total weight (A) and payload (B) of different vehicles. 
by using waste heat available in the engine exhaust stream and cooling system.

\section{CONCLUSIONS AND FUTURE WORKS}

This study presents a system for $\mathrm{CO}_{2}$ capture from the exhaust stream of an internal combustion engine. Energy and exergy analyses of the $\mathrm{CO}_{2}$ capture system has been performed in details. Three $\mathrm{CO}_{2}$ capture system designs have been compared, and adsorption-desorption on vehicle with liquid $\mathrm{CO}_{2}$ product found to be better than the other two designs. The system design includes integration of temperature swing adsorption, Rankine cycle, heat pump (i.e., cold generation), and $\mathrm{CO}_{2}$ compression and liquefaction on vehicle. The proposed system design has energy self-sufficiency, as it converts waste heat available in the exhaust stream into mechanical power (via Rankine cycle) to drive the heat pump compressor and product compressors. The captured $\mathrm{CO}_{2}$ can store renewable energy by converting product $\mathrm{CO}_{2}$ into green fuels using co-electrolysis. About $90 \%$ of the carbon present in the fuel can be recycled using $\mathrm{CO}_{2}$ capture system, and the remaining $10 \%$ carbon can be supplied from the biomass. This study compares conversion of captured $\mathrm{CO}_{2}$ into methane, methanol, DME and gasoline. Further, percentage added weights of $\mathrm{CO}_{2}$ capture system and liquid storage for several vehicles are calculated, that shows high potential for the integration of $\mathrm{CO}_{2}$ capture in the transportation sector. Finally, weights of on-board hydrogen storage for fuel cell electric vehicle and $\mathrm{CO}_{2}$ capture system with liquid storage for conventional diesel vehicle are compared.

This study is an initial effort for capturing $\mathrm{CO}_{2}$ from vehicles, and it may require several years to realize such system in practice. In this study, fixed composition and flow rate of the exhaust gas have been assumed, to calculate the heating/cooling requirements

\section{REFERENCES}

Abdelghaffar, W. A., Osman, M. M., Saeed, M. N., and Abdelfatteh, A. I. (2002). "Effects of coolant temperature on the performance and emissions of a diesel engine," in Asme Internal Combustion Engine Division Spring Technical Conference (Rockford, IL), 187-197. doi: 10.1115/ICES2002-464

Al-Najem, N. M., and Diab, J. M. (1992). Energy-exergy analysis of a diesel engine. Heat Recov. Syst. CHP 12, 525-529. doi: 10.1016/0890-4332(92)90021-9

Ashok Leyland Report (2012). Report on CNG Cylinders for Automotive Vehicle Applications. Chennai: Product Development Ashok Leyland Technical Centre.

Bui, M., Adjiman, C. S., Bardow, A., Anthony, E. J., Boston, A., Brown, S., et al. (2018). Carbon capture and storage (CCS): the way forward. Energy Environ. Sci. 11, 1062-1176. doi: 10.1039/C7EE02342A

Casas, N., Schell, J., Joss, L., and Mazzott, M. (2013). A parametric study of a PSA process for pre-combustion CO2 capture. Sep. Purif. Technol. 104, 183-192. doi: 10.1016/j.seppur.2012.11.018

Chen, C., Kotyk, J. F. K., and Sheehan, S. W. (2018). Progress toward commercial application of electrochemical carbon dioxide reduction. Chem 4, 2571-2586. doi: 10.1016/j.chempr.2018.08.019

Clausse, M., Merel, J., and Meunier, F. (2011). Numerical parametric study on $\mathrm{CO}_{2}$ capture by indirect thermal swing adsorption. Int. J. Greenhouse Gas Control 5, 1206-1213. doi: 10.1016/j.ijggc.2011.05.036

Delgado, O., Rodriguez, F., and Muncrief, R. (2017). Fuel Efficiency Technology in European Heavy-Duty Vehicles: Baseline and Potential for the 2020-2030 Time Frame. Berlin: The International Council on Clean Transportation. of the TSA. This choice is suitable for train and ship transports, but exhaust variations are expected for cars, trucks, and buses. Further, steady-state operation of Rankine cycle is very critical, and so an intermediate thermal fluid will be required to store the exhaust heat and to maintain the Rankine cycle operation. In future, dynamic study on the system will be performed. This system analysis and design have several assumptions and uncertainties, which should be improved by experimental data. Hence, we are planning to develop a prototype of the $\mathrm{CO}_{2}$ capture system.

\section{DATA AVAILABILITY STATEMENT}

The raw data supporting the conclusions of this manuscript will be made available by the authors, without undue reservation, to any qualified researcher.

\section{AUTHOR CONTRIBUTIONS}

All authors listed have made a substantial, direct and intellectual contribution to the work, and approved it for publication.

\section{ACKNOWLEDGMENTS}

This research project is financially supported by the Swiss Innovation Agency Innosuisse and is part of the Swiss Competence Center for Energy Research SCCER EIP.

\section{SUPPLEMENTARY MATERIAL}

The Supplementary Material for this article can be found online at: https://www.frontiersin.org/articles/10.3389/fenrg. 2019.00143/full\#supplementary-material

Delphi (2012). Worldwide Emissions Standards-Heavy Duty and Off-Highway Vehicles. Michigan: Delphi.

Dimitrova, Z., and Maréchal, F. (2017). Energy integration on multiperiods for vehicle thermal powertrains. Can. J. Chem. Eng. 95, 253-264. doi: $10.1002 /$ cjce. 22588

Dinker, A., Agarwal, M., and Agarwal, G. D. (2017). Heat storage materials, geometry and applications: a review. J. Energy Inst. 90, 1-11. doi: 10.1016/j.joei.2015.10.002

European Environment Agency (2017). National Emissions Reported to the UNFCCC and to the EU Greenhouse Gas Monitoring Mechanism. Copenhagen: Directorate-General for Environment, United Nations Framework Convention on Climate Change.

Gibson, J. A. A., Mangano, E., Shiko, E., Greenaway, A. G., Gromov, A. V., Lozinska, M. M., et al. (2016). Adsorption materials and processes for carbon capture from gas-fired power plants: AMPGas. Ind. Eng. Chem. Res. 55, 3840-3851. doi: 10.1021/acs.iecr.5b05015

Grelet, V., Reiche, T., Lemort, V., Nadri, M., and Dufour, P. (2016). Transient performance evaluation of waste heat recovery rankine cycle based system for heavy duty trucks. Appl. Energy 165, 878-892. doi: 10.1016/j.apenergy.2015.11.004

Hebbar, G. S. (2014). NOx from diesel engine emission and control strategies-a review. Int. J. Mech. Eng. Rob. Res. 3, 471-482. Available online at: http://www. ijmerr.com/uploadfile/2015/0409/20150409042911754.pdf

Hesselgreaves, J. E. (2001). Compact Heat Exchangers, Selection, Design and Operation. Pergamon: Elsevier Ltd. 
Hossain, S. N., and Bari, S. (2014). Waste heat recovery from exhaust of a diesel generator set using organic fluids. Procedia Eng. 90, 439-444. doi: 10.1016/j.proeng.2014.11.753

Huck, J. M., Lin, L. C., Berger, A. H., Shahrak, M. N., Martin, R. L., Bhown, A. S., et al. (2014). Evaluating different classes of porous materials for carbon capture. Energy Environ. Sci. 7, 4132-4146. doi: 10.1039/C4EE02636E

IPCC (2014). Climate Change 2014: Mitigation of Climate Change. Contribution of Working Group III to the Fifth Assessment Report of the Intergovernmental Panel on Climate Change. Cambridge: Cambridge University Press.

Kanchibhotla, S. A., and Bari, S. (2018). Optimum Design Point to Recover Maximum Possible Exhaust Heat Over the Operating Range of a Small Diesel Truck Using Bottoming Rankine Cycle. Warrendale, PA: SAE International, SAE Technical Paper 2018-01-1377.

Kul, B. S., and Kahraman, A. (2016). Energy and exergy analyses of a diesel engine fuelled with biodiesel-diesel blends containing 5\% bioethanol. Entropy 18:387. doi: $10.3390 / \mathrm{e} 18110387$

Ligterink, N. E., van Zyl, P. S., and Heijne, V. A. M. (2016). Dutch $\mathrm{CO}_{2}$ Emission Factors for Road Vehicles. Utrecht: TNO R10499.

Lu, Y., Roskilly, A. P., Smallbone, A., Yu, X., and Wang, Y. (2017). Design and parametric study of an organic Rankine cycle using a scroll expander for engine waste heat recovery. Energy Procedia 105, 1420-1425. doi: 10.1016/j.egypro.2017.03.530

Luo, X., and Wang, M. (2017). Study of solvent-based carbon capture for cargo ships through process modelling and simulation. Appl. Energy 195, 402-413. doi: 10.1016/j.apenergy.2017.03.027

Majewski, W. A., and Khair, M. K. (2006). Diesel Emissions and Their Control. Warrendale, PA: SAE International. doi: 10.4271/R-303

Maréchal, F., and Kalitventzeff, B. (1998). Process integration: selection of the optimal utility system. Comp. Chem. Eng. 22, 149-156. doi: 10.1016/S0098-1354(98)00049-0

Marx, D., Joss, L., Hefti, M., and Mazzotti, M. (2016). Temperature swing adsorption for post-combustion $\mathrm{CO}_{2}$ capture: Single- and multicolumn experiments and simulations. Ind. Eng. Chem. Res. 55, 1401-1412. doi: 10.1021 /acs.iecr.5b03727

Mian, A., Martelli, E., and Maréchal, F. (2016). Framework for the multiperiod sequential synthesis of heat exchanger networks with selection, design, and scheduling of multiple utilities. Ind. Eng. Chem. Res. 55, 168-186. doi: 10.1021/acs.iecr.5b02104

Ntiamoah, A., Ling, J., Xiao, P., Webley, P. A., and Zhai, Y. (2016). $\mathrm{CO}_{2}$ capture by temperature swing adsorption: use of hot $\mathrm{CO}_{2}$-rich gas for regeneration. Ind. Eng. Chem. Res. 55, 703-713. doi: 10.1021/acs.iecr.5b01384

Proll, T., Schony, G., Sprachmann, G., and Hofbauer, H. (2016). Introduction and evaluation of a double loop staged fluidized bed system for post-combustion $\mathrm{CO}_{2}$ capture using solid sorbents in a continuous temperature swing adsorption process. Chem. Eng. Sci. 141, 166-174. doi: 10.1016/j.ces.2015.11.005

Ribeiro, R. P. P. L., Grande, C. A., and Rodrigues, A. E. (2013). Activated carbon honeycomb monolith - Zeolite $13 \mathrm{X}$ hybrid system to capture $\mathrm{CO}_{2}$ from flue gases employing electric swing adsorption. Chem. Eng. Sci. 104, 304-318. doi: 10.1016/j.ces.2013.09.011

Salvi, B. L., and Subramanian, K. A. (2015). Sustainable development of road transportation sector using hydrogen energy system. Renew. Sust. Energy Rev. 51, 1132-1155. doi: 10.1016/j.rser.2015.07.030
Schaaf, T., Grunig, J., Schuster, M. R., Rothenfluh, T., and Orth, A. (2014). Methanation of $\mathrm{CO}_{2}$ - storage of renewable energy in a gas distribution system. Energy Sust. Soc. 4:2. doi: 10.1186/s13705-014-0029-1

Sharma, S., Rangaiah, G. P., and Maréchal, F. (2017). "Integrated multiobjective differential evolution and its application to amine absorption process for natural gas sweetening," in Differential Evolution in Chemical Engineering: Developments and Applications, eds G. P. Rangaiah and S. Sharma (Singapore: World Scientific), 128-155. doi: 10.1142/97898132075 230005

Shivaprasad, K. V., Rajesh, R., Anteneh Wogasso, W., Nigatu, B., and Addisu, F. (2018). Usage of hydrogen as a fuel in spark ignition engine. Mater. Sci. Eng. 376:012037. doi: 10.1088/1757-899X/376/1/012037

Sprouse, C., III, and Depcik, C. (2013). Review of organic Rankine cycles for internal combustion engine exhaust waste heat recovery. Appl. Ther. Eng. 51, 711-722. doi: 10.1016/j.applthermaleng.2012.10.017

Tock, L., and Maréchal, F. (2014). Process design optimization strategy to develop energy and cost correlations of $\mathrm{CO}_{2}$ capture processes. Comp. Chem. Eng. 61, 51-58. doi: 10.1016/j.compchemeng.2013.10.011

Turton, R., Bailie, R. C., Whiting, W. B., and Shaeiwitz, J. A. (2012). Analysis, Synthesis and Design of Chemical Processes, 4th Edn. New Jersey, NJ: Prentice Hall.

United States Environmental Protection Agency (2016). Inventory of U. S. greenhouse gas emissions and sinks: 1990-2016, EPA 430-R-18-003.

Verdegaal, W. M., Wang, K., Schulley, J. P., Wriedt, M., and Zhou, H.-C. (2016). Evaluation of metal-organic frameworks and porous polymer networks for $\mathrm{CO}_{2}$-capture applications. ChemSusChem 9, 636-643. doi: $10.1002 /$ cssc. 201501464

Verhelst, S., and Wallner, T. (2009). Hydrogen-fueled internal combustion engines. Progress Energy Comb. Sci. 35, 490-527. doi: 10.1016/j.pecs.2009.08.001

Wang, L., Perez-Fortes, M., Madi, H., Diethelm, S., Herle, J. V., and Maréchal, F. (2018). Optimal design of solid-oxide electrolyzer based power-to-methane systems: a comprehensive comparison between steam electrolysis and coelectrolysis. Appl. Energy 211, 1060-1079. doi: 10.1016/j.apenergy.2017.11.050

Wang, Y., Zhao, L., Otto, A., Robinius, M., and Stolter, D. (2017). A review of postcombustion $\mathrm{CO}_{2}$ capture technologies from coal-fired power plants. Energy Procedia 114, 650-665. doi: 10.1016/j.egypro.2017.03.1209

Yang, M. (2016). Numerical study on the heat transfer of carbon dioxide in horizontal straight tubes under supercritical pressure. PLoS ONE 11:e0159602. doi: 10.1371/journal.pone.0159602

Yee, T. F., and Grossmann, I. E. (1990). Simultaneous optimization models for heat integration II. Heat exchanger network synthesis. Comp. Chem. Eng. 14, 1165-1184. doi: 10.1016/0098-1354(90)85010-8

Conflict of Interest: The authors declare that the research was conducted in the absence of any commercial or financial relationships that could be construed as a potential conflict of interest.

Copyright (C) 2019 Sharma and Maréchal. This is an open-access article distributed under the terms of the Creative Commons Attribution License (CC BY). The use, distribution or reproduction in other forums is permitted, provided the original author(s) and the copyright owner(s) are credited and that the original publication in this journal is cited, in accordance with accepted academic practice. No use, distribution or reproduction is permitted which does not comply with these terms. 